\title{
Compounds used to produce cloned animals are genotoxic and mutagenic in mammalian assays in vitro and in vivo
}

\author{
R.J. Oliveira ${ }^{1,2,3,4}$, M.S. Mantovani ${ }^{5}$, A.F. da Silva ${ }^{5}$, J.R. Pesarini ${ }^{2,3}$ \\ M.O. Mauro ${ }^{2,6}$ and L.R. Ribeiro ${ }^{1,7}$ \\ ${ }^{1}$ Programa de Pós-Graduação em Biologia Celular e Molecular, Instituto de Biociências de Rio Claro, \\ Universidade Estadual Paulista, Rio Claro, SP, Brasil \\ ${ }^{2}$ Centro de Estudos em Células Tronco, Terapia Celular e Genética Toxicológica, Núcleo de Hospital Universitário, \\ Universidade Federal de Mato Grosso do Sul, Campo Grande, MS, Brasil \\ ${ }^{3}$ Programa de Pós-Graduação em Saúde em Desenvolvimento na Região Centro-Oeste, \\ Faculdade de Medicina "Dr. Hélio Mandetta", Universidade Federal de Mato Grosso do Sul, Campo Grande, MS, Brasil \\ ${ }^{4}$ Programa de Mestrado em Farmácia, Centro de Ciências Biológicas e da Saúde, Universidade Federal de Mato Grosso do Sul, \\ Campo Grande, MS, Brasil \\ ${ }^{5}$ Departamento de Biologia Geral, Universidade Estadual de Londrina, Londrina, PR, Brasil \\ ${ }^{6}$ Programa de Doutorado em Biotecnologia e Biodiversidade - Rede Pró Centro-Oeste, \\ Universidade Federal de Mato Grosso do Sul, Campo Grande, MS, Brasil \\ ${ }^{7}$ Programa de Pós-Graduação em Patologia, Faculdade de Medicina de Botucatu, Universidade Estadual Paulista, \\ Botucatu, SP, Brasil
}

\begin{abstract}
The compounds 6-dimethylaminopurine and cycloheximide promote the successful production of cloned mammals and have been used in the development of embryos produced by somatic cell nuclear transfer. This study investigated the effects of 6-dimethylaminopurine and cycloheximide in vitro, using the thiazolyl blue tetrazolium bromide colorimetric assay to assess cytotoxicity, the trypan blue exclusion assay to assess cell viability, the comet assay to assess genotoxicity, and the micronucleus test with cytokinesis block to test mutagenicity. In addition, the comet assay and the micronucleus test were also performed on peripheral blood cells of 54 male Swiss mice, $35 \mathrm{~g}$ each, to assess the effects of the compounds in vivo. The results indicated that both 6-dimethylaminopurine and cycloheximide, at the concentrations and doses tested, were cytotoxic in vitro and genotoxic and mutagenic in vitro and in vivo, altered the nuclear division index in vitro, but did not diminish cell viability in vitro. Considering that alterations in DNA play important roles in mutagenesis, carcinogenesis, and morphofunctional teratogenesis and reduce embryonic viability, this study indicated that 6-dimethylaminopurine and cycloheximide utilized in the process of mammalian cloning may be responsible for the low embryo viability commonly seen in nuclear transfer after implantation in utero.
\end{abstract}

Key words: Somatic cell nuclear transfer; 6-Dimethylaminopurine; Cycloheximide; Genotoxic; Mutagenic

\section{Introduction}

The somatic cell nuclear transfer (SCNT) technique is being used to clone a variety of animal species, including cattle, sheep, mice, rats, goats, pigs, cats, rabbits, and horses. As the efficiency of SCNT improves, the technique offers more applications in agriculture, biomedical science, and endangered species preservation.

Animal cloning by SCNT has the potential to improve the productivity of enormously valuable livestock and may eventually prove to be a more economical venture than current breeding methods $(1,2)$. Additionally, SCNT may also provide the ability to produce both embryonic stem cells for therapeutic use and transgenic animals that synthesize large quantities of human proteins for use in medicine $(3,4)$. Furthermore, SCNT can help in understanding gene expression and nuclear-cytoplasmic contributions to cellular function and their respective roles in

Correspondence: R.J. Oliveira, Faculdade de Medicina, Universidade Federal de Mato Grosso do Sul, Cidade Universitária, s/n, 79070-900 Campo Grande, MS, Brasil. Fax: +51-0800-6470710. E-mail: rodrigo.oliveira@ufms.br 
growth, development, and aging $(1,5)$. However, the efficiency of the SCNT procedure and the percentage of live offspring obtained by transfer of the resulting embryos into surrogate recipients remain low in most situations (6).

The success of SCNT techniques depends on a wide range of known factors, including the reconstruction process, culture conditions, and cell cycle stages of both the donor and recipient cells $(6,7)$. Oocyte activation may also be an important component of the precise reprogramming that involves chromatin configuration, histone composition, methylation and acetylation patterns, and genomic imprinting for further development of the embryos (8). Therefore, oocyte maturation is considered an important step in achieving in vitro embryo production, since it is one of the essential elements that determine the success of nuclear transfer and the subsequent development of cloned embryos (9-11). To circumvent this problem, additional treatments with 6-dimethylaminopurine (6-DMAP), a phosphorylation inhibitor, or cycloheximide $(\mathrm{CHX})$, a protein synthesis inhibitor (12), have been used to induce the inactivation of mitosis promoting factor. 6-DMAP has been used to improve in vitro maturation and developmental competence of human and mouse oocytes (13) as well as the successful development of cloned monkey (10) and rabbit (14) embryos. Furthermore, 6-DMAP and $\mathrm{CHX}$, independently or together, have been used in the successful production of cloned mammals, including cattle, rabbits, goats, and horses (15).

These treatments induce the inactivation of mitosis promoting factor (12) and/or cytostatic factor, leading to the resumption of meiosis and entry into the first embryonic cell cycle. Both 6-DMAP and $\mathrm{CHX}$ act nonspecifically as broad-spectrum inhibitors in several metabolic pathways in oocytes and may consequently impair further embryonic development (12). Bovine embryos activated by these chemicals are characterized by abnormal chromosomal complements (16). Retrospective studies of the chromosomal makeup of the embryos of food-producing domestic animals have shown that the incidence of chromosomal alterations appears to be influenced by the methods of embryo handling and production (17). In embryos, chromosomal change is usually associated with reduced developmental potential or impaired viability.

The literature has shown that, regardless of which protocol or animal is used, intrauterine development is rare in all species cloned to date. Although several mammalian species have been cloned successfully using SCNT, the efficiency of neonate development has been low. Cloned embryos produced by SCNT frequently die, are aborted, or develop fetal abnormalities. An investigation is necessary to determine whether these phenomena are due to gene mutations induced by the chemical mutagens used to produce the reconstructed cloned embryos.
The purpose of the present study was to investigate whether 6-DMAP or $\mathrm{CHX}$ are genotoxic or mutagenic, using comet and micronucleus assays in mammals in vitro and in vivo.

\section{Material and Methods}

\section{Experiments in vitro}

Chemical agents. In the cell line HepG2, the directacting alkylating agent methyl methane sulfonate (MMS; CAS No. 66-27-3, Merck, Germany) was used as the positive control at concentrations of $4.23,4.23,12.53$, and $37.60 \mu \mathrm{g} / \mathrm{mL}$ in the comet assay, trypan blue exclusion assay, micronucleus test, and cytotoxicity assay, respectively. The different concentrations were defined in prior pilot experiments for each assay with the aim of determining the lowest effective concentration.

The compounds tested were 6-DMAP (CAS No. 93855-6, Sigma, USA) and CHX (CAS No. 66-81-9, Sigma). The concentrations utilized in the genotoxicity and mutagenicity assays were determined by the colorimetric thiazolyl blue tetrazolium bromide (MTT) assay (CAS No. 298-93-1, Sigma), which was used to determine cytotoxicity. 6-DMAP was tested at 13 concentrations between 0.014 and $60.8 \mathrm{mg} / \mathrm{mL}$, and $\mathrm{CHX}$ was tested at 13 concentrations of 1.25 to $5120 \times 10^{-3} \mathrm{mg} / \mathrm{mL}$ in culture medium.

In the comet, cell viability, and micronucleus assays, the following concentrations were tested: 0.01, 0.10, 0.50, and $1.00 \mathrm{mg} / \mathrm{mL}$ 6-DMAP and $0.16,1.60,16.00$, and $160.00 \times 10^{-3} \mathrm{mg} / \mathrm{mL} \mathrm{CHX}$ in culture medium. These concentrations were determined based on the MTT assay results. Also, an extensive literature review revealed that the concentration of the doses of 6-DMAP and $\mathrm{CHX}$ ranged from 0.0003263 to $0.8159 \mathrm{mg} / \mathrm{mL}(18,19)$ and from 2 to $10 \times 10^{-3} \mathrm{mg} / \mathrm{mL}(20,21)$, respectively.

Cell line. The human hepatic cell line HepG2 utilized in this study was provided by Prof. Dr. Sigfried Knasmüller of the Research Institute of Cancer of the University of Vienna, Austria.

The cells were grown in $25-\mathrm{cm}^{2}$ culture flasks in $10.0 \mathrm{~mL}$ minimum essential medium (Lot 1262854, Cat. 41500-018, Gibco, USA) supplemented with $20 \%$ fetal bovine serum (Gibco) and 1\% sodium pyruvate (Lot 1271397, Cat. 11360-070, Gibco), in a $5 \% \mathrm{CO}_{2}$ incubator $\left(37^{\circ} \mathrm{C}\right)$ until reaching confluence. Under these conditions, the cell cycle time was approximately $24 \mathrm{~h}$.

MTT assay. For the MTT assay, $2.5 \times 10^{4}$ cells/well were seeded on 96-well culture plates. However, the cells were seeded only in columns 2-6 and 8-12, and columns 1 and 7 were filled with only reagents without the presence of cells (designated in the text as blanks). On the plate, the rows were filled with the following treatments: control, positive control (MMS, $\left.37.6 \times 10^{-3} \mathrm{mg} / \mathrm{mL}\right), 6$-DMAP $(0.014$ to $60.8 \mathrm{mg} / \mathrm{mL})$, and $\mathrm{CHX}\left(1.25\right.$ to $\left.5120 \times 10^{-3} \mathrm{mg} / \mathrm{mL}\right)$. The experiments were carried out in duplicate, with five 
replicate plates used for each experiment.

The cells were seeded in a final volume of $100 \mu \mathrm{L}$ culture medium and incubated for a period of $24 \mathrm{~h}$. Medium was added with and without the drugs, for a total volume of $200 \mu \mathrm{L}$ per well. The cells were exposed to the drugs for a period of $30 \mathrm{~h}$. The medium was then discarded, and the plate was incubated at $37^{\circ} \mathrm{C}$ for $3 \mathrm{~h}$ with $150 \mu \mathrm{L}$ MTT diluted in phosphate-buffered saline (PBS) at a concentration of $1.0 \times 10^{-6} \mathrm{mg} / \mathrm{mL}$. Afterward, the MTT solution was discarded, and $100 \mu \mathrm{L}$ dimethylsulfoxide (Lot 16148, Biotec, Brazil) was added. Plates were then read in a plate spectrophotometer (Universal Microplate Reader, ELx 800, Bio-Tek Instruments, USA) using filters for 490 and $630 \mathrm{~nm}$. Values are reported as means \pm standard deviation. Statistical analysis was performed using ANOVA followed by the Tukey-Kramer test $(\mathrm{P}<0.05)$.

Comet assay. The comet assay was performed according to Tice et al. (22), using HepG2 cells that were grown for one complete cycle $(24 \mathrm{~h})$ before the drug treatments for $30 \mathrm{~h}$. The cells $\left(4 \times 10^{6}\right)$ were trypsinized (trypsin-EDTA, $0.1 \%$ ) and harvested. A $20-\mu \mathrm{L}$ aliquot of cell suspension along with $120 \mu \mathrm{L} 1.5 \%$ low melting point agarose at $37^{\circ} \mathrm{C}$ was deposited on a slide precoated with normal agarose (5\%). The slide was covered with a glass coverslip and cooled at $4^{\circ} \mathrm{C}$ for 20 min. Slides were immersed in lysis solution for $1 \mathrm{~h}$. Next, the slides were transferred to electrophoresis buffer for $20 \mathrm{~min}$ for denaturation and then electrophoresed with a $\mathrm{pH}>13.0$ buffer at $4^{\circ} \mathrm{C}$ for $20 \mathrm{~min}$. Afterward, the slides were neutralized, air-dried, and fixed in absolute ethanol for $10 \mathrm{~min}$

Cells on the slides were stained with $100 \mu \mathrm{L}$ ethidium bromide $\left(20 \times 10^{-3} \mathrm{mg} / \mathrm{mL}\right)$ and evaluated using a fluorescence microscope (Nikon, Labophot-2, Japan) at $40 \times$ magnification, using an excitation filter of 420-490 nm and a barrier filter of $520 \mathrm{~nm}$.

Three independent repetitions were performed. Cells (100) were scored per treatment, and the comets were classified as follows: cells without a comet tail (Class 0 ), cells with a tail less than the diameter of the nucleus (Class 1), cells with a tail one to two times the diameter of the nucleus (Class 2), and cells with a tail greater than the diameter of the nucleus (Class 3 ). Apoptotic cells, which had a totally fragmented nucleus, were not counted (23).

The total score was calculated by summing the resultant values after multiplication of the total cells observed in each class of lesion by the number of the class. Statistical analysis was performed using ANOVA followed by the Tukey-Kramer test $(P<0.05)$.

Cell viability assay. After the cells were harvested for the comet assay, a $20-\mu \mathrm{L}$ aliquot of the cell suspension was mixed with $20 \mu \mathrm{L}$ trypan blue $(0.2 \%$; Lot 1275150 , Cat. No. 15250, Gibco, USA). Next, $20 \mu \mathrm{L}$ of this mixture was placed in a Neubauer chamber, and the numbers of viable and nonviable cells were counted in the four outer squares of the chamber using a light microscope. Values are reported as percentages and statistical analysis was performed using the Kruskal-Wallis test $(P<0.05)$.

Micronucleus test with cytokinesis block. Mutagenicity was determined by the micronucleus test using HepG2 cells that had been grown for one complete cell cycle $(24 \mathrm{~h})$ and treated for a period of $30 \mathrm{~h}$ with test agents simultaneously with cytochalasin-B.

The procedures utilized for the assay, cell harvest, preparation of slides, and analysis of cells were carried out according to those described by Phelps et al. (24).

Cell cultures were washed with PBS and trypsinized (trypsin-EDTA, 0.1\%), and cells were harvested. After centrifugation for $5 \mathrm{~min}$ at $26,226.56 \mathrm{~g}$, the supernatant was discarded, and cells were placed in hypotonic $1.5 \mathrm{~mL}$ sodium citrate (1\%) and fixed with a drop of $40 \%$ formaldehyde. Cells were then fixed with $5.0 \mathrm{~mL}$ methanol-acetic acid (3:1) and dropped on slides that had been cleaned and kept in distilled water at $4^{\circ} \mathrm{C}$. After mounting on a film of water, the slides were air-dried and later stained with $5 \%$ Giemsa for 10 min.

Three independent repetitions were performed for each treatment. The criteria for selection of binucleated cells were as follows: i) distinguishable nuclear boundaries by light microscopy; ii) nuclei with similar sizes and the same staining pattern and intensity; iii) main nuclei being well separated or close, but well outlined and not superimposed; and iv) cytoplasmic boundary distinguishable from adjacent cells. The micronucleus, present in binucleated cells, should not be more than one-third the size of the main nuclei and, furthermore, should have the same staining pattern and not be refractive.

A total of 3000 binucleated cells were examined per treatment (1000 cells/treatment/repetition), except for cytotoxic treatments, and the chi-square test $(P<0.05)$ was used for statistical analysis.

The same slides used for the micronucleus test were used to determine the nuclear division index to compare the mitogenic responses and cytostatic effects of the agents tested. According to Salvadori et al. (25), this parameter is calculated using the following formula: $\mathrm{MI}=[\mathrm{M} 1+2(\mathrm{M} 2)+3(\mathrm{M} 3)+4(\mathrm{M} 4)] / \mathrm{N}$, where $\mathrm{M} 1-\mathrm{M} 4$ are the numbers of cells with 1,2, 3, and 4 nuclei, respectively, and $\mathrm{N}$ is the total number of viable cells. Statistical analysis was carried out using ANOVA followed by the Tukey-Kramer test for comparison of means $(\mathrm{P}<0.05)$.

Statistical analysis. The comparison of quantitative results was carried out using parametric (ANOVA/TukeyKramer) and nonparametric tests (ANOVA/KruskalWallis; chi-square test), depending on the nature of the data distribution (26).

\section{Experiments in vivo}

Animals. Male Swiss mice of reproductive age and a mean weight of $35 \mathrm{~g}$ were obtained from the Central 
Animal Facility, Universidade Estadual de Londrina, PR, Brazil. The mice were randomly distributed into groups of three animals per polypropylene cage with hardwood chips as bedding and were maintained under controlled conditions of temperature $\left(22 \pm 2^{\circ} \mathrm{C}\right)$, humidity $(55 \pm 10 \%)$, and a 12:12-h light-dark cycle, with at least 10 changes per hour of filtered air. Food (Nuvital, Brazil) and filtered water were available ad libitum. A minimum period of 7 days was allowed for acclimatization. In this phase, the animals were inspected daily. At the end of the experiment, all animals were killed by cervical dislocation because the use of any anesthetic could interfere with the effects of the chemical compounds under investigation. The euthanasia procedure was selected to minimize pain and stress, in agreement with the guidelines for the ethical treatment of animals, according to the Ethics Committee in Animal Experimentation of the Universidade Estadual de Londrina (Protocol \#72/2005).

Chemicals. Cyclophosphamide (Fosfaseron), an indirect-acting alkylating agent, was obtained from Ítaca Laboratórios (REG. M.S. No. 1.2603.0056.002-1; Batch 063020, Brazil) and used to induce DNA damage. Cyclophosphamide was prepared in $\mathrm{Ca}^{2+}$ - and $\mathrm{Mg}^{2+}$

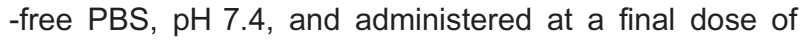
$50 \mathrm{mg} / \mathrm{kg}$ body weight (BW) by the intraperitoneal (ip) route.

6-DMAP and $\mathrm{CHX}$ were also diluted in PBS, and the tested doses $(0.33,3.30,16.50$, and $33.00 \mathrm{mg} / \mathrm{kg} \mathrm{BW}$, ip, for 6-DMAP and 0.053, 0.53, and $5.30 \mathrm{mg} / \mathrm{kg} \mathrm{BW}$, ip, for $\mathrm{CHX)}$ were established in pilot experiments.

Experimental design. Animals were distributed into nine groups (6 animals in each) as follows: group 1 (control) received PBS in a volume of $0.1 \mathrm{~mL} / 10 \mathrm{~g} \mathrm{BW}$, ip; group 2 received cyclophosphamide (a DNA damageinducing agent) at a dose of $50.0 \mathrm{mg} / \mathrm{kg} \mathrm{BW}$, ip; groups 3 to 6 received 6-DMAP at doses of $0.33,3.30,16.50$, and $33.0 \mathrm{mg} / \mathrm{kg} \mathrm{BW}$, ip, respectively; groups 7 to 9 received $\mathrm{CHX}$ at doses of $0.053,0.53$, and $5.30 \mathrm{mg} / \mathrm{kg} \mathrm{BW}$, ip, respectively.

Four hours after the administration of 6-DMAP or $\mathrm{CHX}$, peripheral blood was collected by caudal venipuncture from all experimental groups to evaluate genotoxicity using the comet assay.

Peripheral blood was collected by caudal venipuncture from all of the experimental groups 24,48 , and $72 \mathrm{~h}$ after the administration of 6-DMAP or $\mathrm{CHX}$, to evaluate mutagenicity using the micronucleus assay. These collection times were designated T1 (24 h), T2 (48 h), and T3 (72 h).

Comet assay. The alkaline comet assay was performed under indirect light (22). Briefly, $20 \mu \mathrm{L}$ blood cell suspension was embedded into $120 \mu \mathrm{L} 0.5 \%$ low melting point agarose, which was then layered on a precoated slide with a thin layer of normal melting point agarose. The remaining procedures were performed according to the method already described for the comet assay in vitro $(22,23)$

Comet assay data were analyzed using ANOVA followed by the Tukey-Kramer test. Differences were considered to be statistically significant when $\mathrm{P}<0.05$.

Micronucleus test in peripheral blood cells. Mutagenicity was determined using the micronucleus technique in peripheral blood as described by Hayashi et al. (27). Briefly, a drop of peripheral blood was deposited on a slide previously prepared with a layer of acridine orange $(1.0 \mathrm{mg} / \mathrm{mL})$. The slide was then coverslipped and placed in a freezer $\left(-20^{\circ} \mathrm{C}\right)$ for a minimum of 7 days. Slides were analyzed by fluorescence microscopy, using blue light (488 nm) and an orange filter, with a $100 \times$ objective. A total of 2000 randomly selected cells from each animal were examined for the frequency of micronuclei.

The micronucleus assay data were analyzed using ANOVA followed by the Tukey-Kramer test. Differences were considered to be statistically significant when $\mathrm{P}<0.05$.

\section{Results}

\section{In vitro}

Table 1 presents the MTT assay results. Concentrations of 60.8 and $30.4 \mathrm{mg} / \mathrm{mL}$ 6-DMAP precipitated in the wells of the plate, impeding the test reaction at these concentrations. The two highest concentrations of 6-DMAP (15.2 and $7.6 \mathrm{mg} / \mathrm{mL}$ ) were shown to cause the death of all of the cells in culture because the absorbance values were statistically equal to that of the blank. The concentration of $3.8 \mathrm{mg} / \mathrm{mL}$ was cytotoxic but did not cause death of all of the cells in culture. However, the concentrations between 1.9 and $0.475 \mathrm{mg} / \mathrm{mL}$ showed absorbances similar to those found for the controls, indicating that this compound did not exert a cytotoxic effect at the lower concentrations. The lowest concentrations, $0.237-0.014 \mathrm{mg} / \mathrm{mL}$, showed significantly higher absorbances than the control, indicating the presence of a higher number of cells per well.

In the evaluation of $\mathrm{CHX}$, the highest concentration tested $\left(5120 \times 10^{-3} \mathrm{mg} / \mathrm{mL}\right)$ was found to kill all of the cells; the absorbance reading was similar to that of the blank. Concentrations between 2560 and $320 \times 10^{-3}$ $\mathrm{mg} / \mathrm{mL}$ were cytotoxic, whereas lower concentrations $\left(160-1.25 \times 10^{-3} \mathrm{mg} / \mathrm{mL}\right)$ did not affect cell viability and cell proliferation.

Table 2 presents the data for the comet assay and cell viability. All of the concentrations of 6-DMAP and $\mathrm{CHX}$ tested were found to be genotoxic, except the lowest concentration of $\mathrm{CHX}\left(0.16 \times 10^{-3} \mathrm{mg} / \mathrm{mL}\right)$, and the data did not indicate a dose-response relationship. Genotoxicity, determined by the number of cells with damaged DNA, was essentially the same (99-100) after treatment with all concentrations of 6-DMAP. After $\mathrm{CHX}$ treatment, the number of damaged cells varied from 79.00 to 97.00 . Thus, the increase in frequency of damaged 
Table 1. Mean absorbance values $\pm S D$ in the thiazolyl blue tetrazolium bromide colorimetric assay.

\begin{tabular}{llll}
\hline Treatment & Mean \pm SD & Treatment & Mean \pm SD \\
\hline Blank & $0.0314 \pm 0.0005^{\mathrm{a}}$ & Blank & $0.0295 \pm 0.0007^{\mathrm{a}}$ \\
Control & $0.1859 \pm 0.0016^{\mathrm{c}, \mathrm{d}}$ & Control & $0.1799 \pm 0.0451^{\mathrm{c}}$ \\
MMS & $0.1516 \pm 0.0327^{\mathrm{d}}$ & MMS & $0.1669 \pm 0.0097^{\mathrm{c}}$ \\
6-DMAP $(\mathrm{mg} / \mathrm{mL})$ & & $\mathrm{CHX}\left(10^{-3} \mathrm{mg} / \mathrm{mL}\right)$ & \\
0.014 & $0.2220 \pm 0.1803^{\mathrm{e}}$ & 1.25 & $0.1580 \pm 0.0145^{\mathrm{c}}$ \\
0.028 & $0.2384 \pm 0.0097^{\mathrm{e}}$ & 2.50 & $0.1691 \pm 0.224^{\mathrm{c}}$ \\
0.059 & $0.2253 \pm 0.0226^{\mathrm{e}}$ & 5.00 & $0.1708 \pm 0.0095^{\mathrm{c}}$ \\
0.118 & $0.2164 \pm 0.0129^{\mathrm{e}}$ & 10.00 & $0.1544 \pm 0.0097^{\mathrm{c}}$ \\
0.237 & $0.1974 \pm 0.0249^{\mathrm{d}, \mathrm{e}}$ & 20.00 & $0.1620 \pm 0.0173^{\mathrm{c}}$ \\
0.475 & $0.1555 \pm 0.0123^{\mathrm{c}, \mathrm{d}}$ & 40.00 & $0.1623 \pm 0.0290^{\mathrm{c}}$ \\
0.950 & $0.1288 \pm 0.0226^{\mathrm{c}, \mathrm{d}}$ & 80.00 & $0.1565 \pm 0.0180^{\mathrm{c}}$ \\
1.900 & $0.1231 \pm 0.0027^{\mathrm{c}}$ & 160.00 & $0.1458 \pm 0.0156^{\mathrm{b}, \mathrm{c}}$ \\
3.800 & $0.0946 \pm 0.0175^{\mathrm{b}, \mathrm{c}}$ & 320.00 & $0.1073 \pm 0.0438^{\mathrm{b}}$ \\
7.600 & $0.0386 \pm 0.0019^{\mathrm{a}}$ & 640.00 & $0.1500 \pm 0.0297^{\mathrm{b}}$ \\
15.200 & $0.0352 \pm 0.0028^{\mathrm{a}}$ & 1280.00 & $0.1124 \pm 0.0220^{\mathrm{b}}$ \\
30.400 & - & 2560.00 & $0.1036 \pm 0.0228^{\mathrm{b}}$ \\
60.800 & - & 5120.00 & $0.0374 \pm 0.0044^{\mathrm{a}}$ \\
\hline
\end{tabular}

SD: standard deviation; MMS: methyl methane sulfonate; 6-DMAP: 6-dimethylaminopurine; CHX: cycloheximide. Different letters indicate a statistically significant difference $(\mathrm{P}<0.05$, ANOVA/Tukey-Kramer).

cells after 6-DMAP exposure was approximately 37.45 times that of the control cultures. The increase in DNA damage after treatment with $\mathrm{CHX}$ was 29.59 times that of the control. The indices of cell viability were statistically similar for all the treatments and varied from 81.33 to $87.67 \%$.

The data for the micronucleus test with cytokinesis block and nuclear division index are reported in Table 3. Statistical analysis demonstrated that the lowest concentration of 6 -DMAP tested $(0.01 \mathrm{mg} / \mathrm{mL})$ was not mutagenic and did not reduce the nuclear division index. However, the other three concentrations significantly reduced the nuclear division index and the lowest concentration showed a mutagenic effect.

The two lowest concentrations of $\mathrm{CHX}(0.16$ and $1.60 \times 10^{-3} \mathrm{mg} / \mathrm{mL}$ ) did not cause a reduction in the nuclear division index and had no mutagenic effect. However, the concentration of $1.60 \times 10^{-3} \mathrm{mg} / \mathrm{mL}$ was effective in causing a 2.92-fold increase in mutagenicity. The two highest concentrations of $\mathrm{CHX}$ studied (16.00 and $160.00 \times 10^{-3} \mathrm{mg} / \mathrm{mL}$ ) reduced the nuclear division index and showed mutagenic activity, causing increases in the frequency of micronuclei of 4.22 and 1.80 times that of the control, respectively.

\section{In vivo}

The mean number of damaged cells, the distribution of classes of DNA damage, and the score in the comet assay in peripheral blood cells of mice treated with 6-DMAP and $\mathrm{CHX}$ are reported in Table 4. Statistically significant differences were observed in the total number of damaged cells at the three highest 6-DMAP doses $(3.30,16.50$, and $33.00 \mathrm{mg} / \mathrm{kg} \mathrm{BW}$ ) when compared to the negative control group. At these three doses, 6-DMAP induced a positive genotoxic response, with 15.3 times the number of damaged cells compared to the negative control. The data in Table 4 also show the effect of 6-DMAP-induced DNA damage on the score of the damaged cells. At the three highest doses, the scores were higher than that of the positive control. For $\mathrm{CHX}$ induced DNA damage, the total number of damaged cells was significantly higher than the negative control only after treatment with the highest dose $(5.30 \mathrm{mg} / \mathrm{kg} \mathrm{BW})$, and the frequency of damaged cells was 2.5 times higher than that of the negative control.

Table 5 summarizes the data obtained from the micronucleus test in peripheral blood cells of mice treated with 6-DMAP and $\mathrm{CHX}$, at the three different times ( $\mathrm{T} 1$, T2, and T3) of analysis. After 6-DMAP treatment, a statistically significant difference was observed at $\mathrm{T} 1$ (analysis at $24 \mathrm{~h}$ after treatment) only for the highest dose (33.00 mg/kg BW). 6-DMAP induced a positive mutagenic response 2.5 times greater than that of the negative control. At T2 (analysis at $48 \mathrm{~h}$ after treatment), the mutagenic responses for the two highest doses (15.50 and $33.00 \mathrm{mg} / \mathrm{kg} \mathrm{BW}$ ) were 2.3 and 2.8 times the negative control value, respectively. At T3 (analysis at $72 \mathrm{~h}$ after treatment), all three doses of 6-DMAP induced a positive mutagenic response that ranged from 1.2 to 1.9 times the negative control value.

After treatment with $\mathrm{CHX}$, a positive mutagenic response was produced only at the highest dose 


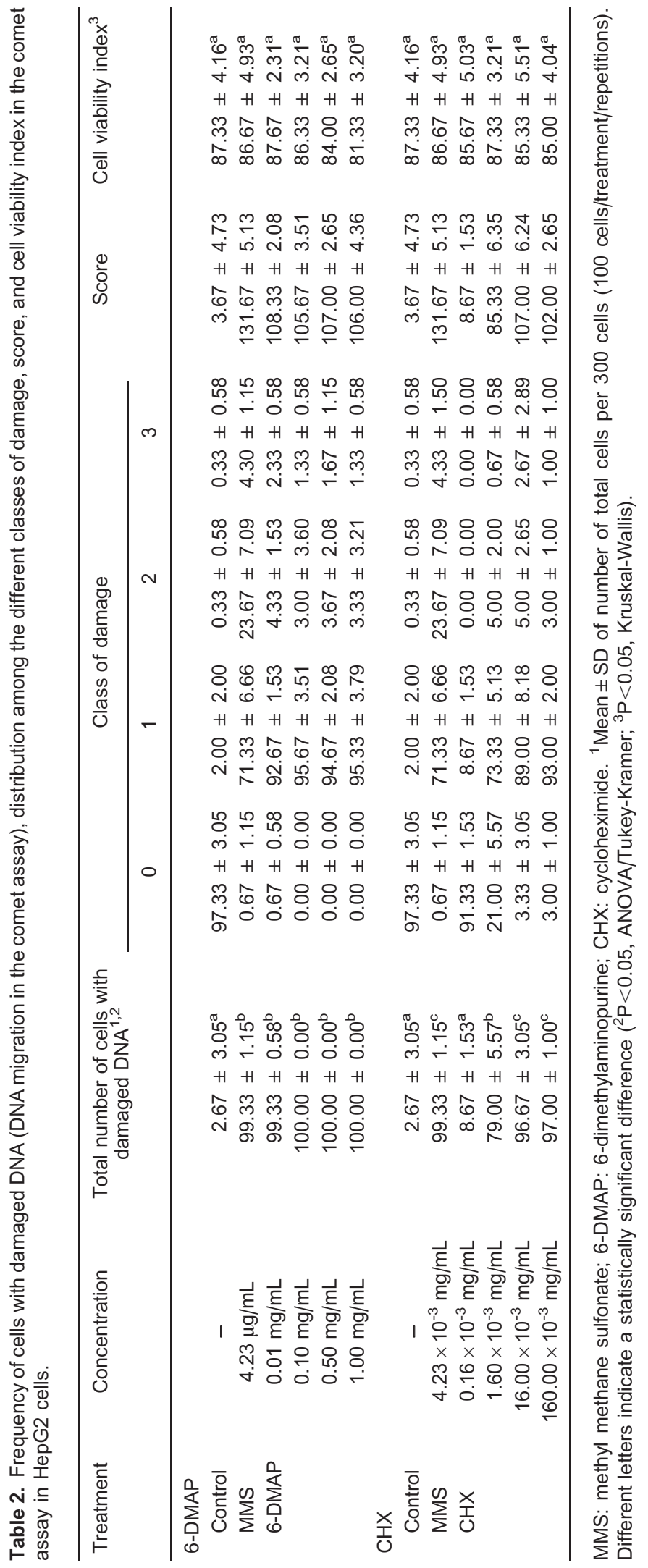


Table 3. Total number of cells analyzed, total number of micronuclei, frequency of micronuclei, and cell division index in the micronucleus test with cytokinesis block in the HepG2 cells.

\begin{tabular}{|c|c|c|c|c|c|}
\hline Treatment & Concentration & $\begin{array}{l}\text { Total number of } \\
\text { cells analyzed }\end{array}$ & $\begin{array}{l}\text { Total number of } \\
\text { micronuclei }^{1}\end{array}$ & $\begin{array}{l}\text { Frequency of } \\
\text { micronuclei (\%) }\end{array}$ & Nuclear division index ${ }^{2}$ \\
\hline \multicolumn{6}{|l|}{ 6-DMAP } \\
\hline Control & - & 3000 & 49 & 1.63 & $1.9227 \pm 0.0323^{b}$ \\
\hline MMS & $12.53 \mu \mathrm{g} / \mathrm{mL}$ & 3000 & $89^{*}$ & 2.97 & $1.8927 \pm 0.0050^{\mathrm{b}}$ \\
\hline \multirow[t]{4}{*}{ 6-DMAP } & $0.01 \mathrm{mg} / \mathrm{mL}$ & 3000 & 38 & 1.27 & $1.9820 \pm 0.0362^{a}$ \\
\hline & $0.10 \mathrm{mg} / \mathrm{mL}$ & 1200 & $42^{*}$ & 3.50 & $1.0620 \pm 0.0080^{c}$ \\
\hline & $0.50 \mathrm{mg} / \mathrm{mL}$ & 551 & 12 & 2.18 & $1.0273 \pm 0.0061^{\mathrm{c}}$ \\
\hline & $1.00 \mathrm{mg} / \mathrm{mL}$ & 715 & 18 & 2.52 & $1.0233 \pm 0.0031^{c}$ \\
\hline \multicolumn{6}{|l|}{$\mathrm{CHX}$} \\
\hline Control & - & 3000 & 49 & 1.63 & $1.9227 \pm 0.0323^{a}$ \\
\hline MMS & $12.53 \times 10^{-3} \mathrm{mg} / \mathrm{mL}$ & 3000 & $89^{*}$ & 2.97 & $1.8927 \pm 0.0050^{\mathrm{a}}$ \\
\hline \multirow[t]{4}{*}{$\mathrm{CHX}$} & $0.16 \times 10^{-3} \mathrm{mg} / \mathrm{mL}$ & 3000 & 56 & 1.87 & $1.8733 \pm 0.0151^{a}$ \\
\hline & $1.60 \times 10^{-3} \mathrm{mg} / \mathrm{mL}$ & 3000 & $143^{*}$ & 4.77 & $1.8733 \pm 0.0284^{a}$ \\
\hline & $16.00 \times 10^{-3} \mathrm{mg} / \mathrm{mL}$ & 3000 & $207^{*}$ & 7.00 & $1.1053 \pm 0.0284^{b}$ \\
\hline & $160.00 \times 10^{-3} \mathrm{mg} / \mathrm{mL}$ & 889 & $88^{*}$ & 9.90 & $1.0473 \pm 0.0061^{\mathrm{c}}$ \\
\hline
\end{tabular}

MMS: methyl methane sulfonate; 6-DMAP: 6-dimethylaminopurine; $\mathrm{CHX}$ : cycloheximide. ${ }^{1}$ Chi-square test: ${ }^{*} \mathrm{P}<0.05$ statistically different compared with control; ${ }^{2}$ ANOVA/Tukey-Kramer test: $\mathrm{P}<0.05$, different letters indicate a statistically significant difference.

(5.30 $\mathrm{mg} / \mathrm{kg} \mathrm{BW})$ at T1, T2, and T3, with values ranging from 1.8 to 1.9 times that of the negative control.

The distribution of the frequency of micronuclei in peripheral blood cells of mice treated with 6-DMAP and $\mathrm{CHX}$ at three different analysis times (T1, T2, and T3) is shown in Figure 1. In groups 1 (control), $3(0.33 \mathrm{mg} / \mathrm{kg}$ 6-DMAP), 8 (0.53 mg/kg CHX), and 9 (5.30 mg/kg CHX), the frequency of micronuclei gradually increased over the three time periods of evaluation. In contrast, in groups 2
(DNA damage-inducing agent), 4 (3.30 mg/kg 6-DMAP) 5 (16.50 mg/kg 6-DMAP), 6 (33.00 mg/kg 6-DMAP), and $7(0.053 \mathrm{mg} / \mathrm{kg} \mathrm{CHX})$, the increase was more substantial at T2 (48 $\mathrm{h}$ after treatment).

Table 6 summarizes the effects found for the test compounds and demonstrates that, considering the different concentrations and doses tested, 6-DMAP and CHX were cytotoxic in vitro and genotoxic and mutagenic in vitro and in vivo, and altered the nuclear division index in vitro.

Table 4. Means $\pm S D$ of cells with damaged DNA, distribution between classes of DNA damage, and score from blood of mice in the comet assay.

\begin{tabular}{|c|c|c|c|c|c|c|c|c|}
\hline \multirow[t]{2}{*}{ Treatment } & \multirow[t]{2}{*}{ Concentration } & \multirow{2}{*}{$\begin{array}{l}\text { No. of cells with } \\
\text { damaged DNA }\end{array}$} & \multicolumn{5}{|c|}{ Class of damage } & \multirow[t]{2}{*}{ Score } \\
\hline & & & 0 & & 1 & 2 & 3 & \\
\hline PBS (G1) & $0.1 \mathrm{~mL} / 10 \mathrm{~g}$ & $6.50 \pm 3.27^{a}$ & $93.50 \pm 3.27$ & 6.33 & \pm 3.27 & $0.17 \pm 0.41$ & $0.00 \pm 0.00$ & $6.67 \pm 3.33$ \\
\hline CPA (G2) & 50.00 mg/kg & $97.33 \pm 3.50^{b}$ & $2.67 \pm 3.50$ & 93.83 & \pm 1.47 & $3.17 \pm 2.48$ & $0.33 \pm 0.52$ & $101.17 \pm 6.62$ \\
\hline \multicolumn{9}{|l|}{ 6-DMAP } \\
\hline G3 & $0.33 \mathrm{mg} / \mathrm{kg}$ & $9.33 \pm 1.75^{a}$ & $89.00 \pm 3.46$ & 9.17 & \pm 1.57 & $0.17 \pm 0.37$ & $0.00 \pm 0.00$ & $9.50 \pm 1.71$ \\
\hline G4 & $3.30 \mathrm{mg} / \mathrm{kg}$ & $99.67 \pm 0.52^{b}$ & $0.33 \pm 0.52$ & 96.50 & \pm 1.64 & $3.17 \pm 1.33$ & $0.00 \pm 0.00$ & $102.83 \pm 1.17$ \\
\hline G5 & $16.50 \mathrm{mg} / \mathrm{kg}$ & $99.67 \pm 0.52^{b}$ & $0.33 \pm 0.52$ & 93.17 & \pm 4.17 & $5.50 \pm 4.32$ & $1.00 \pm 0.89$ & $107.17 \pm 5.12$ \\
\hline G6 & $33.00 \mathrm{mg} / \mathrm{kg}$ & $100.00 \pm 0.00^{\mathrm{b}}$ & $0.00 \pm 0.00$ & 64.00 & \pm 18.42 & $34.67 \pm 18.02$ & $1.33 \pm 0.94$ & $137.33 \pm 18.86$ \\
\hline \multicolumn{9}{|l|}{$\mathrm{CHX}$} \\
\hline G7 & $0.053 \mathrm{mg} / \mathrm{kg}$ & $8.00 \pm 2.45^{a}$ & $92.00 \pm 2.45$ & 7.33 & \pm 1.86 & $0.67 \pm 0.82$ & $0.00 \pm 0.00$ & $8.67 \pm 3.14$ \\
\hline G8 & $0.53 \mathrm{mg} / \mathrm{kg}$ & $8.00 \pm 2.61^{a}$ & $92.00 \pm 2.61$ & 7.67 & \pm 2.25 & $0.33 \pm 0.82$ & $0.00 \pm 0.00$ & $8.33 \pm 3.14$ \\
\hline G9 & $5.30 \mathrm{mg} / \mathrm{kg}$ & $16.50 \pm 3.62^{c}$ & $83.50 \pm 3.65$ & 14.67 & \pm 3.93 & $1.83 \pm 1.17$ & $0.00 \pm 0.00$ & $18.33 \pm 3.70$ \\
\hline
\end{tabular}

G1: phosphate-buffered saline (PBS; negative control); G2: cyclophosphamide (CPA; positive control); G3 to G6: 6-dimethylaminopurine (6-DMAP); $\mathrm{G} 7$ to G9: cycloheximide $(\mathrm{CHX})$. Different letters indicate a statistically significant difference $(P<0.05, A N O V A /$ Tukey-Kramer). 
Table 5. Frequency of micronuclei in the peripheral blood of mice.

\begin{tabular}{|c|c|c|c|c|c|c|c|}
\hline \multirow[t]{2}{*}{ Treatment } & \multirow[t]{2}{*}{ Concentration } & \multicolumn{3}{|c|}{ Total frequency of $\mathrm{MN}^{1}$} & \multicolumn{3}{|c|}{ Mean \pm SD } \\
\hline & & $\mathrm{T} 1$ & $\mathrm{~T} 2$ & T3 & T1 & $\mathrm{T} 2$ & T3 \\
\hline PBS (G1) & $0.1 \mathrm{~mL} / 10 \mathrm{~g}$ & 79 & 91 & 102 & $13.17 \pm 2.86^{a}$ & $15.17 \pm 4.11^{\mathrm{a}}$ & $17.00 \pm 4.24^{\mathrm{a}}$ \\
\hline CPA (G2) & $50.00 \mathrm{mg} / \mathrm{kg}$ & 248 & 325 & 187 & $41.33 \pm 7.26^{b}$ & $54.17 \pm 8.03^{b}$ & $31.17 \pm 12.45^{\mathrm{b}}$ \\
\hline \multicolumn{8}{|l|}{ 6-DMAP } \\
\hline G3 & $0.33 \mathrm{mg} / \mathrm{kg}$ & 78 & 117 & 125 & $13.00 \pm 4.52^{\mathrm{a}}$ & $19.50 \pm 2.59^{a}$ & $20.83 \pm 4.66^{\mathrm{a}, \mathrm{b}}$ \\
\hline G4 & $3.30 \mathrm{mg} / \mathrm{kg}$ & 62 & 129 & 121 & $10.33 \pm 3.88^{a}$ & $21.50 \pm 4.09^{a}$ & $20.17 \pm 6.76^{a, b}$ \\
\hline G5 & $16.50 \mathrm{mg} / \mathrm{kg}$ & 122 & 174 & 79 & $20.33 \pm 7.74^{a}$ & $34.8 \pm 7.76^{c}$ & $23.2 \pm 5.54^{a, b}$ \\
\hline G6 & 33.00 mg/kg & 204 & 172 & 131 & $34.00 \pm 8.05^{\mathrm{b}}$ & $43.00 \pm 5.48^{\mathrm{c}}$ & $32.75 \pm 1.26^{\mathrm{b}}$ \\
\hline \multicolumn{8}{|l|}{$\mathrm{CHX}$} \\
\hline G7 & $0.053 \mathrm{mg} / \mathrm{kg}$ & 92 & 134 & 129 & $15.33 \pm 6.25^{a}$ & $22.33 \pm 2.50^{\mathrm{a}}$ & $21.50 \pm 8.50^{\mathrm{a}}$ \\
\hline G8 & $0.53 \mathrm{mg} / \mathrm{kg}$ & 80 & 126 & 162 & $13.33 \pm 3.78^{a}$ & $21.00 \pm 6.32^{\mathrm{a}}$ & $27.00 \pm 6.90^{\mathrm{a}}$ \\
\hline G9 & $5.30 \mathrm{mg} / \mathrm{kg}$ & 150 & 161 & 197 & $25.00 \pm 5.21^{\mathrm{C}}$ & $26.83 \pm 7.25^{\mathrm{a}, \mathrm{c}}$ & $32.83 \pm 7.88^{a, b}$ \\
\hline
\end{tabular}

MN: micronuclei; SD: standard deviation; G1: phosphate-buffered saline (PBS; negative control); G2: cyclophosphamide (CPA; positive control); G3 to G6: 6-dimethylaminopurine (6-DMAP); G7 to G9: cycloheximide (CHX); T1, T2, and T3: peripheral blood collected at 24, 48, and $72 \mathrm{~h}$ after treatment, respectively. ${ }^{1}$ Total number of MN in 12,000 cells analyzed (2000 cells/animal). Different letters indicate a statistically significant difference $(P<0.05$, ANOVA/Tukey-Kramer).

\section{Discussion}

The results of this study demonstrate that oocyteactivation agents 6-DMAP, a protein serine/threonine kinase (or phosphorylation) inhibitor, and $\mathrm{CHX}$, a protein synthesis inhibitor, have different effects on the induction of genotoxic and mutagenic damage in HepG2 cells and mice.

The in vitro results indicate that both compounds can be cytotoxic at high concentrations. The data indicate that the higher concentrations are capable of killing all of the cells in culture. Lower concentrations also showed cytotoxicity, but did not kill all of the cells. The concentrations of $1.90-0.475 \mathrm{mg} / \mathrm{mL} \mathrm{CHX}$ and $160.0-1.25 \times 10^{-3}$ $\mathrm{mg} / \mathrm{mL}$ 6-DMAP did not affect cell viability, and the concentrations of $0.237-0.014 \mathrm{mg} / \mathrm{mL}$ of 6-DMAP caused an increase in the number of cells. These observations

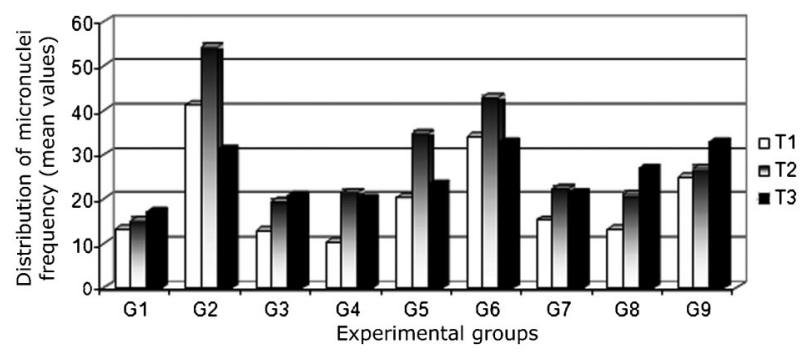

Figure 1. Distribution of the micronuclei frequency (means) in peripheral blood of mice during the $72 \mathrm{~h}$ of experimentation. $\mathrm{G} 1$ : phosphate-buffered saline (PBS; negative control); G2: cyclophosphamide (CPA; positive control); $\mathrm{G} 3$ to $\mathrm{G} 6$ : 6-dimethylaminopurine (6-DMAP); $\mathrm{G} 7$ to G9: cycloheximide (CHX). T1, T2, and T3: collection of peripheral blood at 24,48 , and $72 \mathrm{~h}$ after treatment, respectively. indicate that high concentrations cause damage to cells, leading to death, whereas lower concentrations allow progression of the cell cycle, leading to an increase in the number of dividing cells and thus in the number of cells present on the culture plate.

According to de la Fuente and King (28), treatment of bovine oocytes with $\mathrm{Ca}^{2+}, \mathrm{CHX}$, and 6-DMAP stimulates the reinitiation of the cell cycle in embryonic cells and thereby produces a high rate of blastocyst formation. Therefore, based on studies by Presicce and Yang (29) and Susko-Parrish et al. (12), treatment with 6-DMAP has been suggested to be directly related to the initiation of mitosis for cleavage of the zygote and consequent formation of the blastocyst.

The effects of 6-DMAP on chromatin and microtubule arrangement, which have been the most extensively studied effects, are mediated by inhibition of protein

Table 6. Summary of 6-DMAP and CHX activities.

\begin{tabular}{lcc}
\hline Activity & 6-DMAP & CHX \\
\hline In vitro & & \\
Cytotoxicity & + & + \\
Genotoxicity & + & + \\
RCV & - & - \\
Mutagenicity & + & + \\
RNDI & + & + \\
In vivo & & + \\
Genotoxicity & + & + \\
Mutagenicity & + & + \\
\hline
\end{tabular}

6-DMAP: 6-dimethylaminopurine; CHX: cycloheximide; RCV: reduction in cell viability; RNDI: reduction in nuclear division index; + : presence of activity; -: absence of activity. 
kinases and, consequently, proteins involved in the processes of phosphorylation $(28,30,31)$. The dephosphorylation induced by treatment with 6-DMAP is capable of inactivating the proto-oncogene c-mos and initiating mitosis by activating mitogen-activated protein kinases $(28,32,33)$. This cascade could be the mechanism by which 6-DMAP acts as a mitogen in HepG2 cells in the MTT assay. In the micronucleus test in vitro, the lowest concentration of 6-DMAP $(0.01 \mathrm{mg} / \mathrm{mL})$ showed a significant increase in the nuclear division index, which could have been due to the same inhibitory activity of 6-DMAP in the production of kinases that leads to mitosis.

The comet assay, which showed a good index of cell viability, demonstrated that all of the concentrations of 6-DMAP and $\mathrm{CHX}$, except the lowest concentration of $\mathrm{CHX}$, induced DNA damage. Thus, the use of these agents can produce genetic lesions and compromise the development of the embryo.

The micronucleus test in vitro showed that the three highest concentrations of 6-DMAP reduced the nuclear division index and that only the lowest of these was mutagenic. The results demonstrated that the frequency of micronuclei observed with treatment with the two highest concentrations was less than the frequency observed for the negative control. However, it cannot be inferred that these two concentrations were not mutagenic, because a reduction in the nuclear division index (which was much larger for these two concentrations) can lead to a substantial underestimation of the frequency of micronuclei. This underestimation could occur because the DNA damage could be quantified only in cells that passed through a cycle of cell division and had an interruption in cytokinesis due to the use of cytochalasinB. With respect to $\mathrm{CHX}$, the two lowest concentrations did not reduce the nuclear division index, and only the concentration of $1.60 \times 10^{-3} \mathrm{mg} / \mathrm{mL}$ showed mutagenic activity. The two highest concentrations tested significantly decreased the nuclear division index, and both concentrations were found to be mutagenic. However, it should be noted that the higher concentration was shown to be less mutagenic than $16.00 \times 10^{-3} \mathrm{mg} / \mathrm{mL}$.

Mutagenesis studies of 6-DMAP and $\mathrm{CHX}$ are scarce. However, some studies have indicated that the utilization of these two compounds is associated with alterations in mitosis and meiosis $(10,28,34)$.

A study by de la Fuente and King (28), which was performed using bovine embryos developed by the process of parthenogenesis, demonstrated that an elevated frequency of tetraploid metaphases (which could have been induced by the utilization of 6-DMAP and $\mathrm{CHX}$ ) was related to embryonic mortality. Moreover, Mitalipov et al. (10) have reported, in a study conducted with oocytes of Rhesus monkeys, that one-third of the embryos produced by parthenogenesis extruded one of the two polar bodies containing chromatin, but the ploidy of these embryos was not determined. Thus, it is believed that most pregnancy failures could, in part, be attributed to the high incidence of polyploidy observed in cloned embryos exposed to 6-DMAP $(1,35,36)$. However, alternative treatments with dehydroleucodine combined with cytochalasin B could have better results as oocyte activators than activation by an often-used protocol using ionomycin combined with 6-DMAP (36). Another study (37) showed that DNA damage caused by cell cycle inhibitors could also be evaluated by the presence of phosphorylated histone $\mathrm{H} 2 \mathrm{AX}$ foci (markers of DNA double-stranded breaks). They also showed that treatment with 6-DMAP in transgenic embryos is a promising alternative for transgenic animal production.

The extrusion of genetic material involved the loss of parts of chromosomes or whole chromosomes. Thus, alterations in the cell cycle can result from the use of compounds that interfere with the activation of the oocyte cytoplasm, in parthenogenesis and in the transfer of somatic nuclei to the cytoplast.

Previous studies have reported that treatment with $\mathrm{CHX}$ at a concentration of $1 \mathrm{mM}$ for 6,10 , or $16 \mathrm{~h}$ causes an absence of or alterations in chromosome condensation during cell division and the absence of nuclear envelope fragmentation during prophase (34). Other reports have indicated that, at a concentration of $0.1 \mathrm{mM}$, chromosomes that do not localize adequately in the equatorial plate are later found dispersed, suggesting alterations in the formation of the mitotic spindle $(34,38)$. These events can be related to those that occur in the formation of micronuclei, since these can arise from clastogenic and/or aneugenic damage.

According to Sentein $(34,38)$, treatment with $\mathrm{CHX}$ can produce a reduction in astral expansion, condensation of the centrosphere, and a separation of poles and asters from the nuclei. These three symptoms indicate a weakened polar activity. Cytokinesis is blocked irreversibly after $6 \mathrm{~h}$ of treatment. After $10 \mathrm{~h}$ of treatment, the recovery of cytokinetic activity is possible, but it is not efficient. Treatment for $30 \mathrm{~h}$, as utilized in this study, may favor the appearance of damage, as demonstrated by the micronucleus test in vitro.

When analyzing the percentages of DNA damage, measured by the quantification of cells with micronuclei in vitro in relation to the number of cells analyzed, a doseresponse relationship can be seen for $\mathrm{CHX}$, and the frequency of DNA damage increases with the concentration of the compound. However, this type of relationship could not be demonstrated upon treatment with 6-DMAP because of the drastic reduction in binucleated cells resulting from the interruption of the cell cycle.

In vivo studies were carried out in mice, testing four doses of 6-DMAP and three doses of $\mathrm{CHX}$. In the comet assay, which was performed $4 \mathrm{~h}$ after the administration of the agents, the lowest dose of 6-DMAP did not show genotoxic activity. However, the other three doses displayed genotoxic effects with scores higher than that 
for the positive control, indicating high genotoxic activity. Only the highest dose of $\mathrm{CHX}$ had a genotoxic effect. However, the score for this dose was 5.52 times lower than that of the positive control, indicating a lower genotoxic activity when compared to 6-DMAP.

The assays to determine mutagenicity in vivo were performed at three different times: 24,48 , and $72 \mathrm{~h}$ after the administration of the compounds. At $24 \mathrm{~h}$, both compounds were found to be mutagenic only at the highest dose. At $48 \mathrm{~h}$, the two highest doses of 6-DMAP and the highest dose of $\mathrm{CHX}$ increased the frequency of micronuclei. However, at $72 \mathrm{~h}$ after treatment, mutagenic activity could be observed with all of the doses of 6-DMAP tested and with only the highest dose of $\mathrm{CHX}$.

A comparison of the different times demonstrates that the peak of micronucleus frequency upon treatment with 6-DMAP occurred at $48 \mathrm{~h}$. However, even the lowest dose caused DNA damage at $72 \mathrm{~h}$, suggesting that this compound can exert a mutagenic effect even after being metabolized and later excreted.

The only mutagenic dose of $\mathrm{CHX}$ caused a gradual increase in the frequency of micronuclei over the $72 \mathrm{~h}$ of the experiment, suggesting that the metabolites of $\mathrm{CHX}$ can also exert mutagenic effects. Thus, the peak of micronuclei after treatment with this compound occurred at $72 \mathrm{~h}$. In addition, the three highest doses of 6-DMAP induced a positive genotoxic response, with 15.3 times the number of damaged cells compared with the negative control. 6-DMAP treatment also induced a positive mutagenic response (chromosomal breaks, revealed by the presence of micronuclei) that ranged from 1.2 to 2.8 times that of the negative control, depending on the time of the analysis. The genotoxic activity of $\mathrm{CHX}$ was 2.5 times that of the negative control. The positive mutagenic response was induced only at the highest concentration of $\mathrm{CHX}$ and ranged from 1.8 to 1.9 times that of the negative control, also depending on the time of analysis. These results suggest that 6 -DMAP and $\mathrm{CHX}$ enhance the incidence of DNA damage and chromosomal abnormalities in mammals.

Katoh et al. (39) conducted studies to determine whether 6-DMAP and $\mathrm{CHX}$ are mutagenic agents in bacterial mutagenicity tests. Salmonella typhimurium TA100, TA1535, TA98, and TA1537 and Escherichia coli WP2 uvrA were used as test strains. The authors observed that, although $\mathrm{CHX}$ was not mutagenic in any of the strains, 6-DMAP induced a positive mutagenic response that ranged from 2 to 5 times above background in TA1535.

According to de la Fuente and King (28), the utilization of 6-DMAP and $\mathrm{CHX}$ is related to the successful production of mammalian clones, including those of cattle, rabbits, goats, and horses. However, despite providing satisfactory activation rates, the utilization of 6-DMAP has resulted in aneuploidy in embryos produced using this protocol. This result was corroborated by Katoh et al. (39), who reported that cloned embryos produced by nuclear transfer frequently die, are aborted, or have fetal abnormalities. The authors noted the need for new studies to determine if these adverse events are truly the result of using chemical agents in the process of embryo reconstruction. In addition, Basic-Zaninovic et al. (40) have performed a comprehensive study of the mutagenic effects of $\mathrm{CHX}$ using the Ames test ( $S$. typhimurium TA98 and TA100; Saccharomyces cerevisiae D7), Allium cepa root tip assay, and a micronucleus test in mouse bone marrow. The results demonstrated that there was no increase in frequency or reversion in S. typhimurium, suggesting that $\mathrm{CHX}$ does not induce frameshift or base pair substitution mutations in $S$. typhimurium, regardless of metabolic activation. In $S$. cerevisiae, no mutations were observed that could be determined by gene conversion in this yeast. However, treatment with $\mathrm{CHX}$ significantly diminished viability, indicating toxic effects. In the $A$. cepa root tip test and micronucleus test in bone marrow, treatment with $\mathrm{CHX}$ causes different types of DNA damage that could be determined by chromosomal breaks, mitotic perturbations, and nuclear abnormalities.

A general analysis of the data demonstrates that the two compounds are cytotoxic in vitro, mutagenic in vitro and in vivo, alter the nuclear division index in vitro, and do not affect cell viability in vitro. It should be noted that numeric or structural chromosomal aberrations, caused by clastogenic and/or aneugenic agents, are of major importance in the study of mutagenesis, carcinogenesis, spontaneous abortion, prenatal death, and stillbirth and in the development of offspring with congenital malformations and physiological and/or behavioral alterations. Considering the latter and based on our findings, the present investigation can be viewed as the beginning of these aforementioned studies.

Although other related studies have been reported, our data contraindicate the process of cloning of mammals using 6-DMAP and $\mathrm{CHX}$ and present a hypothesis that improves our understanding of the low viability of embryos produced by nuclear transfer, after their implantation in utero. Studies must still be performed to correlate reproductive performance and teratogenic, morphological, and functional analyses, including the study of learning and physical and reflexologic development, in the progeny of animals produced or treated with 6-DMAP and CHX. These types of studies will lead to greater insight into the effects of these agents.

\section{Acknowledgments}

Research supported by CNPq and CAPES. 


\section{References}

1. Cibelli JB, Stice SL, Golueke PJ, Kane JJ, Jerry J, Blackwell $\mathrm{C}$, et al. Cloned transgenic calves produced from nonquiescent fetal fibroblasts. Science 1998; 280: 1256-1258, doi: 10.1126/science.280.5367.1256.

2. Wells DN, Misica PM, Tervit HR. Production of cloned calves following nuclear transfer with cultured adult mural granulosa cells. Biol Reprod 1999; 60: 996-1005, doi: 10.1095/biolreprod60.4.996.

3. Keefer CL. Production of bioproducts through the use of transgenic animal models. Anim Reprod Sci 2004; 82-83: 5-12, doi: 10.1016/j.anireprosci.2004.04.010.

4. Hwang WS, Ryu YJ, Park JH, Park ES, Lee EG, Koo JM, et al. Evidence of a pluripotent human embryonic stem cell line derived from a cloned blastocyst. Science 2004; 303: 1669-1674, doi: 10.1126/science. 1094515.

5. McCreath KJ, Howcroft J, Campbell KH, Colman A, Schnieke AE, Kind AJ. Production of gene-targeted sheep by nuclear transfer from cultured somatic cells. Nature 2000; 405: 1066-1069, doi: 10.1038/35016604.

6. Wilmut I, Schnieke AE, McWhir J, Kind AJ, Campbell KH. Viable offspring derived from fetal and adult mammalian cells. Nature 1997; 385: 810-813, doi: 10.1038/385810a0.

7. Du F, Sung LY, Tian XC, Yang X. Differential cytoplast requirement for embryonic and somatic cell nuclear transfer in cattle. Mol Reprod Dev 2002; 63: 183-191, doi: 10.1002/ mrd.10172.

8. De Sousa PA, Dobrinsky JR, Zhu J, Archibald AL, Ainslie A, Bosma W, et al. Somatic cell nuclear transfer in the pig: control of pronuclear formation and integration with improved methods for activation and maintenance of pregnancy. Biol Reprod 2002; 66: 642-650, doi: 10.1095/ biolreprod66.3.642.

9. Campbell KH, Loi P, Otaegui PJ, Wilmut I. Cell cycle coordination in embryo cloning by nuclear transfer. Rev Reprod 1996; 1: 40-46, doi: 10.1530/ror.0.0010040.

10. Mitalipov SM, Nusser KD, Wolf DP. Parthenogenetic activation of Rhesus monkey oocytes and reconstructed embryos. Biol Reprod 2001; 65: 253-259, doi: 10.1095/ biolreprod65.1.253.

11. Zhang $H$, Wu B, Liu H, Qiu M, Liu J, Zhang $Y$, et al. Improving development of cloned goat embryos by supplementing alpha-lipoic acid to oocyte in vitro maturation medium. Theriogenology 2013; 80: 228-233, doi: 10.1016/ j.theriogenology.2013.03.027.

12. Susko-Parrish JL, Leibfried-Rutledge ML, Northey DL, Schutzkus V, First NL. Inhibition of protein kinases after an induced calcium transient causes transition of bovine oocytes to embryonic cycles without meiotic completion. Dev Biol 1994; 166: 729-739, doi: 10.1006/dbio.1994.1351.

13. Anderiesz C, Fong CY, Bongso A, Trounson AO. Regulation of human and mouse oocyte maturation in vitro with 6-dimethylaminopurine. Hum Reprod 2000; 15: 379-388, doi: 10.1093/humrep/15.2.379.

14. Dinnyes A, Dai Y, Barber M, Liu L, Xu J, Zhou P, et al. Development of cloned embryos from adult rabbit fibroblasts: effect of activation treatment and donor cell preparation. Biol Reprod 2001; 64: 257-263, doi: 10.1095/ biolreprod64.1.257.

15. Galli C, Lagutina I, Crotti G, Colleoni S, Turini P, Ponderato
$\mathrm{N}$, et al. Pregnancy: a cloned horse born to its dam twin Nature 2003; 424: 635, doi: 10.1038/424635a.

16. Rho GJ, Wu B, Kawarsky S, Leibo SP, Betteridge KJ. Activation regimens to prepare bovine oocytes for intracytoplasmic sperm injection. Mol Reprod Dev 1998; 50: 485492, doi: 10.1002/(SICl)1098-2795(199808)50:4<485::AIDMRD12>3.0.CO;2-1.

17. King WA, Coppola G, Alexander B, Mastromonaco G, Perrault S, Nino-Soto MI, et al. The impact of chromosomal alteration on embryo development. Theriogenology 2006; 65: 166-177, doi: 10.1016/j.theriogenology.2005.09.031.

18. Hou YP, Dai YP, Zhu SE, Zhu HB, Wu TY, Gong GC, et al. Bovine oocytes vitrified by the open pulled straw method and used for somatic cell cloning supported development to term. Theriogenology 2005; 64: 1381-1391, doi: 10.1016/ j.theriogenology.2005.03.012.

19. Saeki K, Nagao Y, Kishi M, Nagai M. Developmental capacity of bovine oocytes following inhibition of meiotic resumption by cycloheximide or 6-dimethylaminopurine. Theriogenology 1997; 48: 1161-1172, doi: 10.1016/S0093691X(97)00349-X

20. Le Beux G, Richard FJ, Sirard MA. Effect of cycloheximide, 6-DMAP, roscovitine and butyrolactone I on resumption of meiosis in porcine oocytes. Theriogenology 2003; 60: 10491058, doi: 10.1016/S0093-691X(03)00124-9.

21. Yi YJ, Park CS. Parthenogenetic development of porcine oocytes treated by ethanol, cycloheximide, cytochalasin B and 6-dimethylaminopurine. Anim Reprod Sci 2005; 86: 297-304, doi: 10.1016/j.anireprosci.2004.07.007.

22. Tice RR, Agurell E, Anderson D, Burlinson B, Hartmann A, Kobayashi $\mathrm{H}$, et al. Single cell gel/comet assay: guidelines for in vitro and in vivo genetic toxicology testing. Environ Mol Mutagen 2000; 35: 206-221, doi: 10.1002/(SICl)10982280(2000)35:3<206::AID-EM8>3.0.CO;2-J.

23. Kobayashi $H$, Sugiyama $C$, Morikawa $Y$, Hayashi M, Sofuni T. A comparison between manual microscopic analysis and computerized image analysis in the single cell gel electrophoresis assay. MMS Communications 1995; 2: 103-115.

24. Phelps JB, Garriott ML, Hoffman WP. A protocol for the in vitro micronucleus test. II. Contributions to the validation of a protocol suitable for regulatory submissions from an examination of 10 chemicals with different mechanisms of action and different levels of activity. Mutat Res 2002; 521: 103-112, doi: 10.1016/S1383-5718(02)00221-8.

25. Salvadori DMF, Ribeiro LR, Fenech M. Teste do micronúcleo em células humanas in vitro. In: Ribeiro LR, Salvadori DMF, Marques EK (Editors), Mutagênese ambiental. Canoas: ULBRA; 2003. p 201-219.

26. Oliveira RJ, Salles MJ, da Silva AF, Kanno TY, Lourenco $A C$, Freiria GA, et al. Effects of the polysaccharide betaglucan on clastogenicity and teratogenicity caused by acute exposure to cyclophosphamide in mice. Regul Toxicol Pharmacol 2009; 53: 164-173, doi: 10.1016/j.yrtph.2008. 12.007.

27. Hayashi M, Morita T, Kodama Y, Sofuni T, Ishidate M Jr. The micronucleus assay with mouse peripheral blood reticulocytes using acridine orange-coated slides. Mutat Res 1990; 245: 245-249, doi: 10.1016/0165-7992(90)90 153-B. 
28. de la Fuente R, King WA. Developmental consequences of karyokinesis without cytokinesis during the first mitotic cell cycle of bovine parthenotes. Biol Reprod 1998; 58: 952-962, doi: 10.1095/biolreprod58.4.952.

29. Presicce GA, Yang X. Nuclear dynamics of parthenogenesis of bovine oocytes matured in vitro for 20 and 40 hours and activated with combined ethanol and cycloheximide treatment. Mol Reprod Dev 1994; 37: 61-68, doi: 10.1002/ mrd.1080370109.

30. Szollosi MS, Kubiak JZ, Debey P, de Pennart H, Szollosi D, Maro B. Inhibition of protein kinases by 6-dimethylaminopurine accelerates the transition to interphase in activated mouse oocytes. J Cell Sci 1993; 104 (Part 3): 861-872.

31. Rime H, Neant I, Guerrier P, Ozon R. 6-Dimethylaminopurine (6-DMAP), a reversible inhibitor of the transition to metaphase during the first meiotic cell division of the mouse oocyte. Dev Biol 1989; 133: 169-179, doi: 10.1016/00121606(89)90308-4.

32. Verlhac $\mathrm{MH}$, de Pennart $\mathrm{H}$, Maro $\mathrm{B}$, Cobb MH, Clarke HJ. MAP kinase becomes stably activated at metaphase and is associated with microtubule-organizing centers during meiotic maturation of mouse oocytes. Dev Biol 1993; 158 : 330-340, doi: 10.1006/dbio.1993.1192.

33. Verlhac MH, Kubiak JZ, Clarke HJ, Maro B. Microtubule and chromatin behavior follow MAP kinase activity but not MPF activity during meiosis in mouse oocytes. Development 1994; 120: 1017-1025.

34. Sentein P. Nuclear and mitotic abnormalities produced by cycloheximide in the newt egg during cleavage and their relationship to the cell cycle. Exp Cell Biol 1981; 49: 98-117.

35. Alexander B, Coppola G, Di Berardino D, Rho GJ, St John $E$, Betts $\mathrm{DH}$, et al. The effect of 6-dimethylaminopurine (6-DMAP) and cycloheximide ( $\mathrm{CHX}$ ) on the development and chromosomal complement of sheep parthenogenetic and nuclear transfer embryos. Mol Reprod Dev 2006; 73 20-30, doi: 10.1002/mrd.20372.

36. Canel N, Bevacqua R, Fernandez-Martin R, Salamone DF. Activation with ionomycin followed by dehydroleucodine and cytochalasin B for the production of parthenogenetic and cloned bovine embryos. Cell Reprogram 2010; 12: 491-499, doi: 10.1089/cell.2009.0109.

37. Bevacqua RJ, Pereyra-Bonnet F, Olivera R, Hiriart MI, Sipowicz P, Fernandez-Martin R, et al. Production of IVF transgene-expressing bovine embryos using a novel strategy based on cell cycle inhibitors. Theriogenology 2012; 78 57-68, doi: 10.1016/j.theriogenology.2012.01.020.

38. Sentein P. Inhibition of spindle assembly by colchicine and of cell cycle by cycloheximide. Comparison and combination of their cytological action on cleavage mitoses. Exp Cell Biol 1979; 47: 368-391.

39. Katoh M, Araki A, Ogura T, Valdivia RP. 6Dimethylaminopurine (6-DMAP), which is used to produce most cloned animals, is mutagenic in Salmonella typhimurium TA1535. Mutat Res 2004; 560: 199-201, doi: 10.1016/ j.mrgentox.2004.03.003.

40. Basic-Zaninovic T, Papes D, Franekic J. Cycloheximide genotoxicity in in vitro and in vivo test systems. Mutat Res 1991; 263: 203-210, doi: 10.1016/0165-7992(91)90002-L. 